\title{
Intermédialités
}

Histoire et théorie des arts, des lettres et des techniques

Intermediality

History and Theory of the Arts, Literature and Technologies

\section{The Suspension of History in Contemporary Media Arts}

\section{Christine Ross}

Numéro 11, printemps 2008

Travailler (Harun Farocki)

Working (Harun Farocki)

URI : https://id.erudit.org/iderudit/037541ar

Aller au sommaire du numéro

Éditeur(s)

Centre de recherche sur l'intermédialité

ISSN

1705-8546 (imprimé)

1920-3136 (numérique)

Découvrir la revue

Citer cet article

Ross, C. (2008). The Suspension of History in Contemporary Media Arts.

Intermédialités / Intermediality, (11), 125-148.
Résumé de l'article

Cet article examine le tournant temporel qui soutient le développement des arts médiatiques depuis la fin des années 1980 : l'exploration du temps comme passage. S'appuyant sur une étude de cas (les installations médias de l'artiste français Melik Ohanian), l'article démontre que ce tournant implique un éventail de stratégies perceptuelles par lesquelles les prémisses temporelles de la modernité classique - l'histoire comme progrès et succession, ce que le philosophe Yuval Dolev désigne comme le " devenir présent d'événements futurs et puis leur devenir passé » — sont suspendues, problématisées et transformées à même cette suspension. Le travail d'Ohanian, ancré dans une pratique de simultanéité, est central à cette élaboration de formes alternatives de récits historiques, où le futur se voit accorder un rôle charnière renouvelé. 


\title{
The Suspension of History in Contemporary Media Arts
}

\author{
Christine Ross
}

S

ince Lessing's Laocoön (1766) the question of time in visual arts has been presented as a problem to be overcome ${ }^{1}$ through a variety of aesthetic strategies that both sustain and sidestep painting's and sculpture's material limitations that allegedly confine them, in contrast to poetry, to the representation of a "single moment of time" and "single vantage point."2 Following this aesthetics, art can only but suggest (and not represent) the temporal deployment of bodies in space, notably by selecting the moment in a given narrative most likely to confer "free reign" to the spectator's imagination. Challenging this enduring rule and attempting to widen the restrictive register of the momentary, contemporary art has positioned itself as a pivotal site of temporal experimentation. Refuting the Lessing-inspired "presentness" of formalist modernism - the timeless immersion in formal composition defended by Michael Fried in his infamous article "Art and Objecthood" (1967) which denounced the phenomenological deployment of endless duration in the experience of the artwork-contemporary aesthetics has generated pictorial and photographic as well as time-based practices (performance, installation, video and new media) that inscribe the spectator in different experiences of duration: the ephemerality and theatricality of the artwork (two predominant traits of contemporary art), the slowing down, condensation or acceleration of the media image that extends, abbreviates or speeds up the perceptual experience of the artwork, the rejection of linear progression, of all resolution in fine. It has also questioned, narratively and formally, the conventions

1. Sections of this paragraph were initially co-written by Johanne Lamoureux and myself for the presentation of Dyschronie de l'image, a colloquium organized in the context of the ACFAS annual congress in May 2006.

2. Gotthold Ephraim Lessing, Laocoön: An Essay on the Limits of Painting and Poetry [1766], trans. Edward Allen McCormick, Indianapolis and New York, The Bobbs-Merrill Company, 1962, p. 19 . 
of historical time of classical modernity - the subordination of time to space and movement, time as equal flow, the permanence of the monument, together with the notion of history as progress, project, and telos. In the fields of art history and aesthetics, a whole repertoire of concepts sustain the historical and philosophical reflection of this critique: the time-image of Nouvelle Vague cinema (Deleuze), the anti-monument (Huyssen), warped space (Vidler), post-memory (Sturken), time in ruins (Augé), chronophobia (Lee), anachronism as "an opening of history" (Didi-Huberman), anachrony as a mean to define new temporal switchings (Rancière), the return of the baroque (Bal), the archaeological impulse (Foster), the affective body as what enframes digital information and allows for the generation of time-consciousness (Hansen), the u-chronic time of digital figuration (Couchot), heterochrony (Bourriaud), ${ }^{3}$ and contemporaneity as what discloses "the multiple ways of being with, in, and out of time, [...] with others and without them". ${ }^{4}$

Many of these concepts have been proposed to disclose contemporary art's increased attention to the historical narrative, namely to methods of archaeology and archival research as well as the role of memory, oblivion, utopia, progress, difference and fiction in the construction of the récit historique. But in the midst of these temporal experimentations and most significantly since the 1980s, media arts have set into play a unique, amplified, preoccupation with the passage of

3. Gilles Deleuze, L'image-temps, Paris, Les Éditions de Minuit, coll. “Critique”, 1985; Andreas Huyssen, Twilight Memories: Marking Time in a Culture of Amnesia, London and New York, Routledge, 1995 and Present Pasts: Urban Palimpsests and the Politics of Memory, Stanford, Stanford University Press, coll. "Cultural Memory in the Present", 2003; Marita Sturken, "Imaging Postmemory/Renegotiating History," Afterimage 26, n 6 , May/June 1999, p. 10-12; Anthony Vidler, Warped Space: Art, Architecture, and Anxiety in Modern Culture, Cambridge, MIT Press, 2002; Marc Augé, Le temps en ruines, Paris, Éditions Galilée, coll. "Collection Lignes fictives", 2003; Pamela M. Lee, Chronophobia: On Time in the Art of the 1960s, Cambridge, MIT Press, 2004; Georges Didi-Huberman, Devant le temps: histoire de l'art et anachronisme des images, Paris, Les Éditions de Minuit, coll. "Critique", 2000 and L'image survivante. Histoire de l'art et temps des fantômes selon Aby Warburg, Paris, Les Éditions de Minuit, coll. "Paradoxe", 2002; Jacques Rancière, "Le concept d'anachronisme et la vérité de l'historien," L'inactuel, n 6, 1996, p. 53-68; Mark B.N. Hansen, New Philosophy for New Media, Cambridge, MIT Press, 2004; Edmond Couchot, Des images, du temps et des machines dans les arts et la communication, Arles, Éditions Jacqueline Chambon/Actes Sud, 2007.

4. Terry Smith, "Creating Dangerously, then and now," in Okwui Enwezor, (ed.), The Unhomely: Phantom Scenes in Global Society, $2^{\text {nd }}$ International Biennial of Contemporary Art of Seville, Sevilla: BIACS, 2006, p. 120. 
time, one that has remained largely under-examined despite its crucial impetus to bridge physical, philosophical, social and historical concepts of time. The field involves a range of perceptual strategies through which the temporal premise of classical modernity — what philosopher Yuval Dolev designates as "the becoming present of future events and then their becoming past"-is suspended and problematized in this very suspension. ${ }^{5}$ At issue in these works are: the malleability of time (its acceleration, compression, and extendedness); its level of reality (is time a real thing that is all around us, or is it nothing more than a way of speaking about and measuring events?); a tenseless defiance to the notion of the flow of time; a spatialization of history which propels its verticality into a horizontal deployment; the simultaneity of events and vantage points rather than their succession; the aesthetic requirement to inhabit the present; and the need to attend to the unequal allocation of time. ${ }^{6}$

These media practices interrupt the passage of time. Yet, their interruption cannot be confused with the "interruptive" montage aesthetics of the historical avant-garde, the dada, surrealist, constructivist, readymade fragmentation and heterogeneous re-association of words, objects, sounds or images to suspend, denounce and collapse specific myths and ideologies. It does not have the intensity of the avant-garde "act" described by Alain Badiou, the aesthetic rupture by which the avant-garde seeks to dissociate itself from the past by creating something radically new, an event that inscribes art in the present. ${ }^{7}$ On the contrary, the past prevails under the forms of archives, memories, or passed perceptions although its tensed relation to the present and the future is broken; and intensity has slipped into temperance. More importantly, the suspension procedure cannot be separated from François Hartog's historian observation (and he is not alone in this observation-let us think of Badiou himself, but also Jean-Luc Nancy, Bruno Latour, Fredric Jameson, Mark Hansen, and others), according to which the prevailing regime of historicity of our epoch is not the liberating access to the present (as was still the case with the avant-garde) but presentism: the withdrawal

5. Yuval Dolev, Time and Realism: Metaphysical and Antimetaphysical Perspectives, Cambridge, MIT Press, 2007, p. viii and 170.

6. On the unequal allocation of time, which motivates the artist, in the words of media theorist Siegfried Zielinski, "to appropriate, or reappropriate, the power of disposal over the time that life and art need," see Siegfried Zielinski, Deep Time of the Media: Toward an Archaeology of Hearing and Seeing by Technical Means, Cambridge, MIT Press, 2006, p. 29.

7. Alain Badiou, Le siècle, Paris, Éditions du Seuil, coll. "Ordre philosophique", 2005 . 
into the present, the turning of the present or even more so, immediacy, into an absolute value, whose absoluteness now means a significant disconnection from the past (perceived as lost) and the future (perceived as increasingly uncertain). In this prevalent regime, it is in fact the possibility of history which is on the threshold of being lost: historical time is suspended. Recent media art partakes of this suspension. But its aesthetics is certainly more generative than the regime to which it belongs. The temporal suspensions are to be sure a means of thinking about time as time for the sake of time. They must be seen as a string of efforts to generate alternative forms of temporality through this very suspension: simultaneity, extended instants, anachronisms, returns, delays in real time, and lateralized longues durées. These regenerations, and this is what singularizes them, are set into play by a series of 'post-optical' strategies, which partake of contemporary art's questioning of the paradigm of opticality (the Wölfflinian view of vision as whole and immediate, as a disembodied process that 'unifies' what is $\operatorname{seen}^{8}$ ). It is through aesthetic strategies which put into crisis the spectator's perceptionthe unifying, binding function of perception - that media arts can be said to address the time-related stakes of our epoch, what philosopher Jean-Luc Nancy has designated as the contemporary suspension of history and time, in which temporality does not disappear but is in fact deployed as a form of spacing or presentism; in which spacing itself becomes a temporal operation. Temporal critique is a perceptual critique.

Media artists involved in the questioning of the passage of time-I am thinking here, notably, of Melik Ohanian, Akram Zaatari, the Atlas Group, Lyne Lapointe, Tacita Dean, Craigie Horsfield, Harun Farocki, Candice Breitz, Eve Sussman \& the Rufus Corporation, Stan Douglas, Bill Viola, Julieta Aranda, Angela Bulloch-coalesce (a coalescence which I believe to be fundamental) two specific aesthetic operations: (1) a refutation of or indifference to the passage of time and (2) perceptual limitedness. My claim will be that this combination is a dynamic one, for it is through the phenomenology of perceptual limitedness - the spectator's experience of a fallible perception, especially in its binding function-that the suspension of time is both experienced and disclosed but also potentially unlocked and released to activate a temporal passage outside the parameters of progress, teleology and linear succession. The significance of this coalescence comes from its presentist context. I want to propose here that the media work of French artist Melik Ohanian, which evolves around the

8. Sebastian Zeidler, introduction to Carl Einstein, Critical Dictionary: “Nightingale’ The Etchings of Hercules Seghers”, trans. Charles W. Haxthausen, October, $n^{\circ}$ 107, Winter 2004, p. 210. 
practice of simultaneity, is an original contribution to this line of investigation. His media installations are key to the understanding of simultaneity as a producer of alternative forms of historical narratives, in which futurity plays a renewed pivotal role, although in potentia more than in the work per se. This essay seeks to examine the relationship between simultaneity, alternative history, perception, and futurity, by focusing on three specific installations but also by situating these works in the context of current historical and philosophical debates on the passage of time. Occupied by the following two questions- "How is temporal passage provisionally disregarded, even denegated, aesthetically?" and "Why does this specific media aesthetics matter? - , it shows that media art's suspension of time is an active appropriation and response to the contemporary - presentist-suspension of history.

Let me start with a very brief description of three recent media works by Melik Ohanian. First, Hidden (2005), a 60 min DVD video projection transmitting a static shot of a sunset in an oil field: the landscape sequence contains within its digital encoding an invisible image only made visible by the simultaneous projection of that very image in another city and whose cryptographed configuration is "exposed" in real time by a computer located next to the screen. In a 2006 version, the installation co-projected in two galleries, in Paris and in Amsterdam, the hidden image of each other's visible image-an oil field

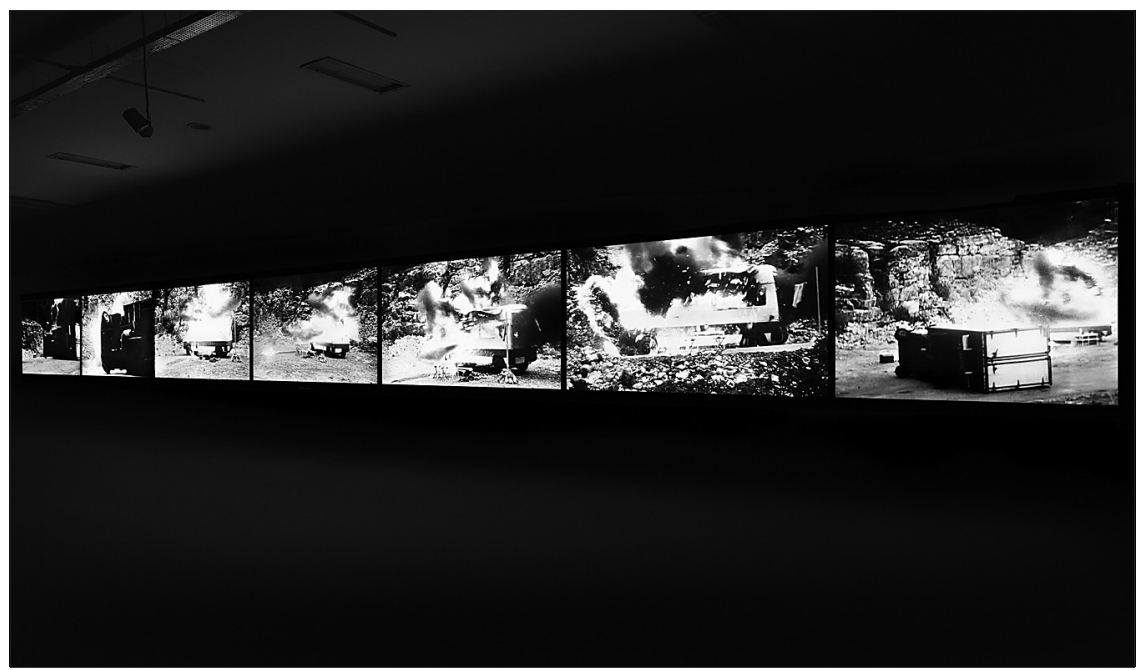

Fig. 1: Seven minutes before, 2004.

Melik Ohanian, Seven minutes before, 2004, 7 synchronized video projections, Beta Digital on DVD with DTS Sound, 28 speakers and 7 bass boxes, $7 \times 21 \mathrm{~min} .2800 \times 1200 \mathrm{~cm}$. Courtesy of the artist, KRISTALE Company, and Galerie Chantal Crousel, Paris. 
in Floresville, Texas and an oil field in Baku, Azerbaijan. The simultaneity of the two projections marginalized the passage of time to disclose the thickness of a single image in one moment in time, which always hides another image of and in another spacetime. But it only paradoxically succeeded in doing so by making the other image inaccessible and imperceptible. Second, Seven Minutes Before (2004, fig. 1), a 28 meters-long seven-screen DVD video projection, whose 21 minute orchestration is shown in a continuous loop. Key to the overall structure is the quasi-panoramic unfolding of the installation: the screens are horizontally adjacent to each other and show parallel views of a small valley in the French Vercors. The series of images were taken simultaneously by seven cameras. The camera trajectories were synchronized at the moment of shooting and the seven projected series of images - devoid of montage and submitted to a negligible number of cuts - were made to correspond to each of these singular trajectories. When we speak here of simultaneity, it is important to emphasize that it governs both the Digital Beta filming in the Vercors and the DVD projection in the gallery. Interestingly, as in Hidden (fig. 2), the installation inscribes the viewer in a perceptual impossibility: it is physiologically unfeasible to see the seven screens all at once but, again, as one experiences this impossibility, history starts to unfold not as a progression but as a lateral display of temporal multiplicities in one moment in time, which suggests a contemporaneity of different times but one that can never be grasped as a whole.

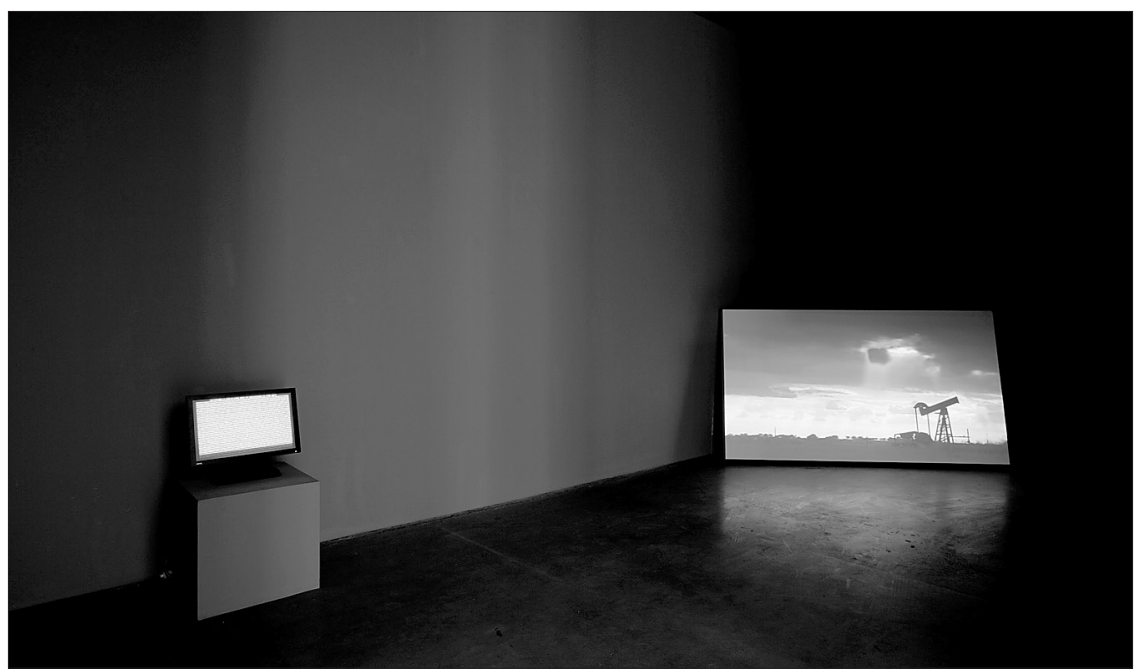

Fig. 2: Melik Ohanian, Hidden, 2005, DVcam on DVD with sound, PC computer and program, 60 min. (c) Florian Kleinefenn. Courtesy of the artist, Galerie Chantal Crousel, Paris, and Yvon Lambert, New York. 
Thirdly September 11, 1973_Santiago, Chile (2007, fig. 3), the main focus of this essay, a single-screen video projection which, despite its apparent straightforwardness, has the particularity of inserting the spectator between image and sound, between the seeing of mute images of Santiago, Chile, in 2007 and the hearing of the sound track of The Coup d'Etat (El golpe de estado), part II of Patricio Guzmán's documentary trilogy The Battle of Chile (La batalla de Chile) released between 1975 and 1979. In this installation, Ohanian has introduced a film archive but has also managed to alter it in a significant way. The Coup d'Etat chronicles, through a mixed montage of Guzmán's own footage and news footage, the demise of the democratically elected Unidad Popular government of Salvador Allende (1970-73). It covers the period leading to the 1973 Chilean military coup, from the unsuccessful military overthrow of Allende's government in June 1973 to Allende's final speech and the aerial bombing of La Moneda, the presidential palace, which finally led to his death. Ohanian's installation, however, has only kept the sound component of the archive to re-synchronize it with video images pertaining to Santiago today, thirty-four years after the military coup, which were shot by Ohanian himself at the exact locations where the events filmed by Guzmán in 1973 took place. In its co-transmission of sounds and images extracted from two different sources, the installation reintroduces simultaneity as the structuring temporality of the installation and, with it, another perceptual impossibility which also partakes of a fragmentary approach

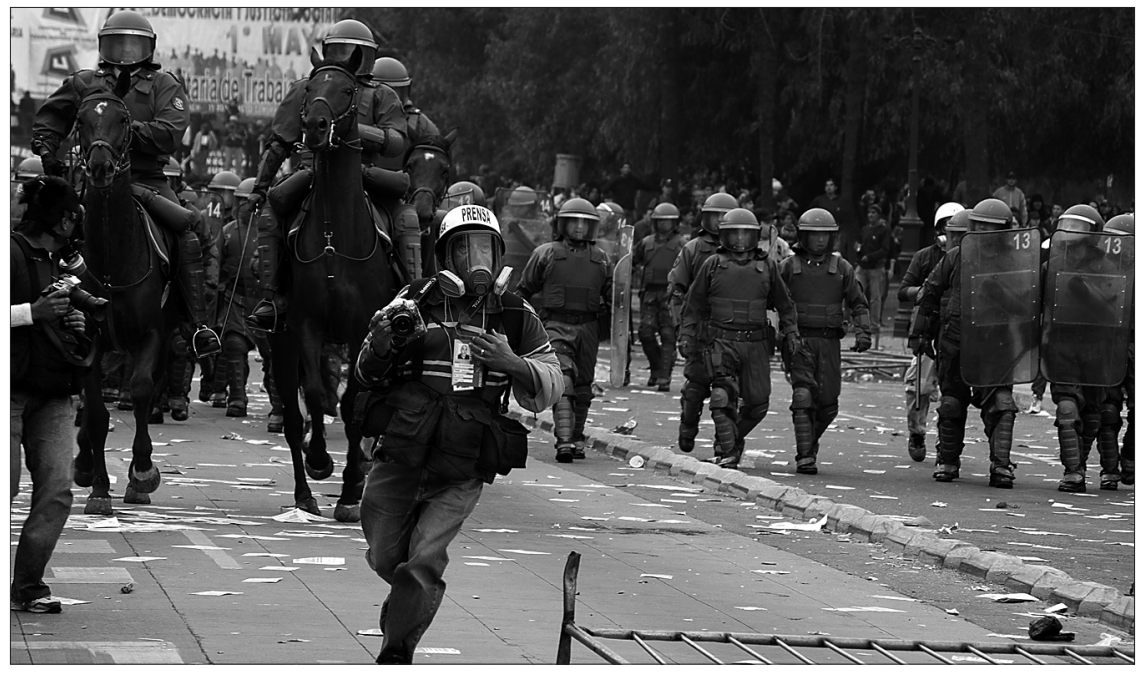

Fig. 3: Melik Ohanian, September 11, 1973 _ Santiago, Chile, 2007, HD video on DVD with ambiant sound, 90 min. Courtesy of the artist, Galerie Chantal Crousel, Paris, and Yvon Lambert, New York. 
to representation that blocks the unifying principle of opticality: the unattainable reconciliation of vision and aurality. It also articulates, at a level which indicates a shift in Ohanian's work, what I would call a temporalization of the spatial dimension of simultaneity whereas earlier installations pertained to a spatialization of time. It is now sounds about the past and images about the present which are made to synchronize with uneasiness.

Simultaneity, the simultaneity of events: a temporality, or more precisely a temporal relation, that appears simple (which the Oxford English Dictionary briefly defines as "existing, happening, occurring [...] at the same time; coincident in time") and yet, one that has historically been at the center of a variety of philosophical and physical conceptualizations of time, and one that must be seen as a mobilizer for innovative redeployments of the image. Key to Ohanian's work is Einstein's 1905 Special Relativity whose main outcome is that all judgments involving time "are always judgments of simultaneous events" inasmuch as we understand simultaneity to be not an absolute but a frame-dependent relationship. Two events are simultaneous if they occur at the same time but their simultaneity depends on the clock of the observer, which means that for another observer, one event may be measured to precede or follow the other.

In September 11, 1973_Santiago, Chile, the simultaneity of transmission of discordant yet place-related sounds and images is compelling in its exploration of relativity, fractionalization, and temporal suspension. Indeed, although sound and image meet materially through synchronization, they obstinately fail to meet temporally: they are part of two realities that cannot blend to create the passage of time-the becoming present of future events and then their becoming past. The soundtrack belongs to a world of socialist struggle, a dialectics between the people and military power, communism and capitalism. Removed from its initial footage, it unfolds as an aural deployment of military technology sounds (helicopters, tanks, gunshots, explosions) and a progression of debates, speeches, claims, and declarations made by the main protagonists of this troubled period: workers, communist leaders, Allende himself, pro-Allende and anti-Allende generals, leaders from the Christian Democracy Party and the National Party, a variety of participants involved in strikes, factory sieges, political meetings, and

9. Albert Einstein, “Zur Elektrodynamik bewegter Körper," in Annalen der Physik (17), 1905, p. 891-921, reprinted in The Collected Papers of Albert Einstein, trans. Anna Beck and Peter Havas, Princeton, Princeton University Press, 1987, vol. 2, p. 275-306, quoted in Max Jammer, Concepts of Simultaneity: From Antiquity to Einstein and Beyond, Baltimore, Johns Hopkins University Press, 2006, p. 94. 
demonstrations, all engaged in the reacting to and thinking of the revolutionary and anti-revolutionary processes, as well as the decision-making required to act accordingly to one's position. In sharp contrast, the visual rendering of Santiago today presents us close-up views of everyday passers-by walking in the city, vacant public squares, empty cemeteries, monuments and memorials which no one seems to be looking at, a completely restored La Moneda devoid of any sign of past bombardment, meaningless images of Allende presented as mere byproducts, all of which are interspersed with images of guards and military figures whose continual attendance varies from a harmless military fanfare to the armed surveillance of semi-public buildings and places to the forceful police intervention during a workers' otherwise pacifist street demonstration. These intervals are not without disclosing the predominant being-there of forces of order in democratic Chilean everyday life and the impoverishment of public life coming from this persistency. September 11, 1973_Santiago, Chile starts with the first sounds of Guzmán's The Coup d'Etat-the flying helicopters of the June 29 failed coupexceptionally overlapping with both the soundtrack and the images of two young boys in today's Chile singing about their hope for a better future; it ends with The Coup d'Etat's written statement of hope ("History is ours, it's made by the people") only to be preceded, however, by the unhopeful simultaneous transmission of the victory speeches of the generals responsible for the final coup and the infamous stadium today, here empty, restored and cleaned up, where the detention, tortures, executions and disappearing of prisoners were infamously operated.

As pointed out by historian Steve Stern, Chile is a memory box made out of dissimilar views of the past, conflicting "emblematic memories" about the coup, remembered either as a salvation (as the event that saved the country), an unresolved rupture, a process of persecution and awakening, or simply as a box that must remain closed. ${ }^{10}$ These memory struggles, argues Stern, are central to the understanding of the Pinochet dictatorship years and Chile's progressive transition to democracy. By recovering one of the key filmic archives documenting the military coup, September 11, 1973_Santiago, Chile is not without engaging with the act of remembering but I believe that its fundamental concern is elsewhere, not in memory per se. Compared to two key recent films on contemporary Chile to which I will briefly come back further down-Patricio Guzmán's Chile, la Memoria Obstinada, (Obstinate Memory, 1997) and Ken Loach's contribution

10. Steve J. Stern, Remembering Pinochet's Chile: On the Eve of London 1998, Durham, Duke University Press, 2004. 
to the collective film 11'09"O1 - September 11 (2002), both featuring witnesses of the coup and the Pinochet regime, films strongly mobilized by the requirement to remember the past despite the melancholia it might (and does) entail when memory disengages with the present-the present is visually brought in, to be confronted with a past that remains fragmented and isolated from the present. What matters here is the fissure between past and present, not mainly the disclosing of but the spectator's perceptual experience of that fissure. The fissure prevents memory from settling in, more or less comfortably, in the past.

Indeed, on the one hand, the installation brings aurally to the surface a past which has already been lost, repressed, distorted, or forgotten, which remains unresolved collectively. This resurfacing cannot be equated to a recovering of the past as an absolute or to the re-establishment of the lost continuity between past and present: the two temporalities are displayed through fractionalized documents and their respective realities scarcely match. The suspension of history lies precisely in this disclosure of a temporal coexistence which is also a discontinuity, a fissure similar to Doris Salcedo's recent intervention-the creation of a 167 meters-long crack in the cement floor of the Turbine Hall of the Tate Modern in London (Shibboleth, 2007)-which starts as a simple fracture but ends up as a border that one may cross but which persists as a rupture, a negative space evoking "the hole of History that marks the $[. .$.$] difference that$ separates whites from non-whites," a difference that is "bottomless, like the division between people."11 Time here refuses to pass and flow even if you jump over it as a game: both installations (Salcedo's and Ohanian's) equalize the past and the present as coexisting but un-passing temporalities. On the other hand, however, September 11, 1973_Santiago, Chile engages the spectator in a perceptual and cognitive split between irreconcilable images and sounds, an irreconcilability that sets into play a necessary processing of heterogeneous realities. This processing, and this is my main claim, becomes the condition of possibility of a sense of futurity. In other words, the suspension of "the historical condition" (Paul Ricœur's postulate that the three tenses of temporality, present, future, past, are inseparable) is not an end in itself. Rather, it is an aesthetic strategy inseparable from a regeneration of historical time, the spectator's necessary engagement in the perceptual dissymmetry between sound and image. To understand this paradoxical continuum, one must consider the three main contextual principles which sustain it: (1) a historical principle, laid out by historian Reinhart Koselleck,

11. Doris Salcedo, quoted in "Doris Salcedo à la Tate Modern (London 5)," Le Monde, October 25th, 2007, http//ucileee.blog.lemonde.fr/2007/10/25/doris-salcedo-a-latate-modern-londres-5 (our translation). 
according to which historical time, since modernity, corresponds to an expanding asymmetry between past and future, between spaces of expectation and horizons of expectation; (2) a tenseless principle according to which the past, the present and the future are not tensely related but equally real; and (3) a narrative or representational principle following which there is no historical time without narrativity and no narrativity without an observer, even in cases where narrativity is radically reinvented in its opposition to the modern concept of history as progress, project, telos. These three principles, I hope to show, are the means by which a transformed sense of historical time is elaborated through its very suspension.

\section{THE HISTORICAL PRINCIPLE}

Recent developments in historiography, especially in France in the work of Pierre

Nora and Paul Ricœur, have lead to an important reassessment of the discipline of history after its fundamental socio-economic reshaping by the school of the Annales between the 1930s and 1960s. Ohanian's investigation of historical time is best understood in the context of this reassessment. Characteristic of this shift is the "return" of the event which had been significantly devalued by Fernand Braudel, one of the main protagonists of the Annales, in his focus on the quasiimmobile history of longue durée in opposition to event history based on the valorization of short time. The shift also involves a renewed attention to oblivion, memory, testimony, and the central role of the witness in the making and writing of history. Time does not allow me here to draw a decent picture of these complex developments but I do want to call attention to the historiographical work of François Hartog which proceeds to historicize the memory-driven reorientation of the discipline of history. His Régimes d'historicité: présentisme et expériences du temps (2003) is a key study on how different historical periods elaborate different orders of time and how "presentism" has become, especially since the 1980s, the prevailing regime of historicity of our epoch. Presentism is an order of time characterized not only by a removal into the present but an absorption of the past and the future in the present. In this prevalent regime, temporal passage dissolves, bringing us at the doorstep of what literary critic Fredric Jameson calls the end of temporality: "a dramatic and alarming shrinkage of existential time and the reduction to a present that hardly qualifies as such any longer, given the virtual effacement of that past and future that can alone define a present in the first place." ${ }^{22}$

12. Fredric Jameson, “The end of temporality," Critical Inquiry, vol. 29, n 4 , Summer 2003 , p. 708 . 
Hartog's analysis is based on the observation of recent events-namely, the collapse of communism, the last major political utopia, materialized in the fall of the Berlin Wall in 1989; consumer society's ever-increasing valorization of the ephemeral; the mass-media compression of time; tourism; the phenomenon of mass lay-outs and its insertion of the unemployed in a project-less temporalityall of which have played a pivotal role in "the present's progressive invasion of the horizon," a present which is "increasingly inflated, hypertrophied."'3 His assessment is also based on the observation of the now vast western preoccupation for conservation and the related revalorization of memory, genealogy, patrimony, and commemoration, made evident in France by Nora's seminal 1984 Lieux de la mémoire, practices that not only marginalize the notion of the future but also document the past in light of the present. But it is likewise considerably indebted to Reinhart Koselleck's understanding of modern historical time as the distance that increasingly separates the space of experience and the horizon of expectation. For Koselleck, modernity is a moment of rupture, whose emphasis on progress breaks with the pre-seventeenth-century peasant-artisan world based on the continuity of the past and the future, in which expectation "subsisted entirely on the experience of their predecessors, experiences which in turn became those of their successors. ${ }^{114}$ Endowed with promises of progress, change, perfectibility, novelty, fulfilment, and opportunity, all of which were supported by technoindustrial and scientific invention, modernity articulates an increasing asymmetry between memory and hope, between experience (the present past, whose past events "have been incorporated and can be remembered" in the present) and expectation (the future made present, which "directs itself to the not-yet, to the nonexperienced, to that which is to be revealed"). ${ }^{15}$ Meanwhile, the accelerating pace of the modern world shaped by developments in communications and rates of production left human agents with briefer time spans to experience the present "as the present," an increased brevity by which the self-accelerating temporality "escapes into a future" while placing heavier and heavier demands on that future. ${ }^{16}$

13. François Hartog, Régimes d'historicité: présentisme et expériences du temps, Paris, Éditions du Seuil, coll."Librairie du Xxi ${ }^{\mathrm{e}}$ siècle," 2003, p. 12, 125 and 126 (our translation).

14. Reinhart Koselleck, "Space of Experience and Horizon of Expectation: Two Historical Categories," in Futures Past: On the Semantics of Historical Time, trans. Keith Tribe, New York, Columbia University Press, 2004, p. 264-265.

15. Reinhart Koselleck, "Space of Experience and Horizon of Expectation: Two Historical Categories," in Futures Past: On the Semantics of Historical Time, p. 259.

16. Reinhart Koselleck, "Modernity and the Planes of Historicity," in Futures Past: On the Semantics of Historical Time, p. 22. 
Hartog argues that modernity's asymmetrical relationship between the space of experience and the horizon of expectation has now reached a moment of quasi-rupture in which "the engendering of historical time seems suspended." ${ }^{17}$ The present resurfaces after its modern devalorization but only as a "worried" present, anxious about the catastrophes of that past that it seeks to overcome, and the anticipated catastrophes of the future that it seeks to avoid; about a future which ceases to be a promise or a principle of faith to become a threat for which we are all fully responsible. ${ }^{18}$ "This future, he writes, is not anymore the luminous horizon towards which we walk, but a shadow line that we have activated towards ourselves, while we seem to mark time in the zone of the present and ruminate a past which does not pass." ${ }^{19}$ Today's increased consideration of the irreparable and the irreversible; the insistence on attitudes of precaution and responsibility; the reiterated recourse to notions of patrimony, memory, and debt: all of these disquiet practices partakes of a present that has extended both into the past and the future.

The distance between Chile's past and present elaborated in September 11, 1973_Santiago, Chile, affirms Hartog's diagnosis of presentism and the related requisite to address the contemporary fate of the asymmetry between spaces of experience and horizons of expectation, in which the past and the future disappear under the umbrella of the present. Indeed, the installation's sound-image simultaneity discloses the rupture between the two temporalities within the now of the spectator's attention. Even the spaces don't seem to relate. Yet, the presentist sense of preservation of the past for the sake of the present, the sense of the past as a piling up of catastrophes, and the sense of the future as an apprehended catastrophe: this triad is significantly absent from Ohanian's address. After all, an archive-even in its fragmented state-is brought back and confronted with the present, an operation that exposes a conviction: the necessity to consider these dissimilar temporalities together despite or because of the distance that separates them. And the sense of the catastrophic appears nowhere in the installation. Presentism, the suspension of time and history, might well be the regime of historicity that informs September 11, 1973_Santiago, Chile, it is not what the work reinforces. On the contrary, Ohanian's suspension of time should be understood as expressing a continuum between presentism and a disintegration of

17. François Hartog, Régimes d'historicité: présentisme et expériences du temps, p. 28.

18. François Hartog, Régimes d'historicité: présentisme et expériences du temps, p. 132.

19. François Hartog, Régimes d'historicité: présentisme et expériences du temps, p. 206. 
presentism, an aesthetics that turns the presentist suspension of history to which it belongs into a suspension of time that might, under specific conditions, open up the process of history.

In the area of aesthetics, Jacques Rancière has already identified-and here he implicitly supports Hartog's diagnosis-how recent art contributes to the generalized catastrophist relation to the future, a perspective that puts an end to the aesthetic undertaking of emancipation inherited from the historical avantgarde. Jean-François Lyotard's defence of the sublime is a key manifestation of this shift, in which art must continually grieve the lie underlying its promise of emancipation and activate "infinite justice" for "infinite evil." 20 Paradoxically, as Rancière argues, this presentism is sustained by a theology of time, "the idea of modernity as a time dedicated to the accomplishment of an internal necessity, yesterday glorious and today disastrous." ${ }^{21}$ The present requirement, then, if one is to give back to art and politics their ability to make a difference, is to refuse the phantasm of their purity and to reconfirm "their quality as cuts, which are always ambiguous, precarious, and litigious."22 This conception entails the abandonment of pivotal concepts of modern history, including the theology of time, original trauma and anticipated salvation or damnation. I am suggesting here that September 11, 1973_Santiago, Chile is an actualization of this requirement. In anticipation of what I will be arguing further down, the originality of this installation lies in its attempt to dig out, through its simultaneous structure, the possibility of a future liberated both from the modern telos scheme and the presentist presumption of catastrophe.

\section{THE TENSELESS PRINCIPLE}

To actualize this condition, the installation elaborates, as is the case with Seven Minutes Before and Hidden which both centre on a single moment in time, what must be called a tenseless view of time, one that substantially challenges both the representation of the passage of time and the representation of time as a dimension of change. As Yuval Dolev has persuasively observed, one of the major philosophical debates informing the conception of time today concerns the dispute between the tensed perspective which "defends the reality of time's passage within a framework in which the present is conceived as 'ontologically

20. Jacques Rancière, Malaise dans l'esthétique, Paris, Éditions Galilée, coll. “La philosophie en effet", 2004, p. 170-171 (our translation).

21. Jacques Rancière, Malaise dans l'esthétique, p. 172 (our translation).

22. Jacques Rancière, Malaise dans l'esthétique, p. 173 (our translation). 
privileged' with respect to the past and the future" and the tenseless analytical perspective which "denies the reality of the distinction between the past, present and future and so of time's passage." ${ }_{23}$ The tenseless view-a view I believe to be fundamental to Ohanian's reiterated exploration of simultaneity-holds that all events, be them past, present or future, are equally real, that they are on an "ontological par." It is based on the understanding that the relationship between the past, present and future is governed not by tensed relations but by relations of precedence, succession, and simultaneity. The tenseless view supports one of the important findings of Einstein's Special Relativity: the fact that time is a physical thing, a malleable, flexible and mutable matter. In the words of physicist Paul Davies: "The major upshot of [Einstein's] new theory of relativity $[. .$.$] was the$ prediction that time and space are not, as Newton had proclaimed, simply there, fixed once and for all in an absolute and universal way for all observers to share. Instead, they are in some sense malleable, able to stretch and shrink according to the observer's motion." ${ }^{24}$ By aesthetically privileging the tenseless simultaneity of the past and the present, September 11, 1973_Santiago, Chile is not representing how the past has marked the present or how the present will be transformed in the future (how, in short, these temporalities tensely interact) but displays the past and the present as simultaneous. This tenseless reality is not just a matter of philosophical debate but more decisively a historical observation. If Koselleck and Hartog are right, the modern distance between the past and the future, between the space of experience and the horizon of expectation, has reached a moment of near rupture: this growing distance entails a decrease of tensed relations and a corresponding increase in tenselessness.

If there is, as philosopher of science Hilary Putnam has postulated in his assessment of Einstein's Theory of Special Relativity, no privileged foliation of spacetime-if, therefore "all inertial frames of reference are metaphysically on par with each other"-then we have to accept that "the contents of all regions of space-time" are "equally real."25 In other words, my state of motion does not have greater authority than yours "when it comes to defining what is, and what is not, real from the perspective of our shared here-now."26 By aesthetically

23. Yuval Dolev, Time and Realism: Metaphysical and Antimetaphysical Perspectives, p. VIII.

24. Paul Davies, About Time: Einstein's Unfinished Revolution, New York, Simon \& Schuster Paperbacks, 1995, p. 53.

25. Michael Lockwood, The Labyrinth of Time: Introducing the Universe, Oxford, Oxford University Press, 2005, p. 57.

26. Michael Lockwood, The Labyrinth of Time: Introducing the Universe, p. 57. 
deploying a heterochronic view of space in a single moment, lateralizing as it does the different histories of each temporal layers of a singular landscape, Seven Minutes Before materializes this parity. Likewise, by aesthetically deploying the simultaneity of the past and the present, September 11, 1973_Santiago, Chile is not representing how the past has marked the present or how the present will be transformed in the future (how, in short, these temporalities tensely interact) but operates a past-present equalization, which is necessarily relativistic.

Dolev is accurate in pointing out how both the tensed and tenseless conceptions of time depend on a problematic ontological claim about real time (both camps rely on the following de-contextualized metaphysical assumption: "the idea that there is an ontology here waiting to be fleshed out"), but he also emphasizes that the tenseless view does not challenge the persistence of our tensed experiences - the fact, for example, that we change and grow older as time passes, or that we remember the past and anticipate the future. The tenseless camp argues more precisely that the past, present and future are experienced, spoken of and thought of as distinct and passing, but that this passing does not concern "the things we experience, think, and speak about." ${ }^{27}$ September 11, 1973_Santiago, Chile aesthetically maintains this nuance as a strategy of historical consciousness, for the tenseless rendering of time that refuses to pass and flow, i.e. time's suspension, progressively makes possible a post-tensed view which admits a renewed passage of time. Why? Because the suspension of time, here, engages the spectators in the duration of perception and compels them to process the temporal asymmetries. The installation introduces an archive, Patricio Guzmán's The Coup d'Etat, simultaneously with Ohanian's own video document of Santiago, Chile today. It does so following a procedure akin to Doris Salcedo's Shibboleth but also to the main aesthetic tradition the Tate Modern installation is indebted to: Gordon Matta-Clark's house cuts, emblematically operated in his 1974 Splitting project. This procedure entails the splitting of a document (a house for Matta-Clark, a museum floor for Salcedo, a film for Ohanian) that exposes what exists beyond the document and now entering the document: an outside, a spectator, a community, a city, a planet, other images, other temporalities. The soundtrack of The Coup d'Etat is released as it were to let another fractionalized document (Santiago, 2007) interact with it. In short, the simultaneity of sounds about the past and images about the present doesn't simply disclose today's gap between temporal categories but invites the spectator to experiment these sound-

27. Yuval Dolev, Time and Realism: Metaphysical and Antimetaphysical Perspectives, p. 6 (emphasis added). 
image oscillations, to perceptually struggle with the oscillating discrepancies so that he or she might establish innovative temporal relations.

\section{THE NARRATIVE PRINCIPLE}

This is where narrativity comes in, via dissymmetry, for it is the spectator who must negotiate the gaps between sound and image, the past and the present; as it is the spectator who negotiates, in Hidden, the non-perceivable distance between the images of gallery one and gallery two; in Seven Minutes Before, the distance between frame-block 1, frame-block 2, and frame-block 3; and in September 11, 1973_Santiago, Chile, the distance between sound and image. This is not merely an intellectual engagement but first and foremost a perceptual one. What is the spectator perceptually negotiating in Ohanian's works if not the heterochrony of a specific in time or of a specific space in time? This negotiation is invisible in the installations and never represented by Ohanian. Without the spectator's phenomenal engagement in such negotiations, there is no representation of historical time, no passage of time, no human time. The burden, the responsibility, is on her. In contrast to Guzmán's Chile, la Memoria Obstinada and Ken Loach's contribution to 11'09"O1 - September 11 (2002), witnessing is not what a spectator looks at or listens to but what the spectator sets into play herself within the confrontation of temporally un-flowing pasts and presents. His works engage the spectator in what cognitive psychology calls the "binding problem"-the association of different features of an object so that it may be perceived as a single object or the association of objects so that they may be perceived as connected-which arises mainly because the brain's processing of information is carried out through several systems analyzing more or less separately the different features of the object. The whole point of Seven Minutes Before, as well as Hidden and September 11, 1973_Santiago, Chile, is that they discourage binding while making use of the exhibition space as "glue." 28 The spectator keeps struggling (a struggle that confirms Bergson's view that perception is about duration) within this binding effort required for the establishment of the historical condition.

It is the active fractionalization of two archives presented simultaneously and the perceptual crisis activated by such a fractionalization in the viewer

28. Edward E. Smith and Stephen M. Kosslyn, Cognitive Psychology: Mind and Brain, Upper Saddle River, New Jersey, Pearson Prentice Hall, 2007, p. 69. Smith and Kosslyn, two cognitive psychologists, use the term glue in their discussion of the binding problem-space can function as a glue mechanism that resolves perceptual binding difficulties. 
that make Ohanian's work a unique player in what art historian Hal Foster has labelled "the archival impulse" of contemporary art, an impulse Foster uncovers in works which, as is the case with September 11, 1973_Santiago, Chile "make historical information, often lost or displaced, physically present" through the fragmentary use of archives. Foster's insightful uncovering falls short, however, of addressing what happens to concepts and practices of time, history and perception in this very process. ${ }^{29}$ The perceptual experience sustained by September 11, 1973_Santiago, Chile is certainly more complex than a mere mismatch. The spectator here is interpellated in his or her contemporaneity both as a media multitasker-a performer of simultaneous media tasks shaped by the imperative of time management-and as a viewer perceptually trained by image-sound film synchronization, by what musician and video artist Chris Marclay has called the subliminal dimension of sound in cinema-the fact that sound conditions the visual experience of the image by directing the emotions of the viewer in ways that reinforce the representational order of illusion. Sound is more powerful than the image and makes the image adhere to it. $3^{\circ}$ Ohanian is absolutely aware of the inseparability of temporal and perceptual critique. He solicits us as multitaskers (in our supposed ability to listen and look at two different media stimuli at the same time) but makes us fail in that task: multitasking becomes what most psychologists now call task switching, a switching that delays image-sound adherence.

The de-synchronization and re-synchronization of image and sound also work to weaken the image-sound adherence. However, it cannot completely erase it. The subliminal authority of sound, the ways in which it orients the perception and meaning of the image or the ways in which-once divided from the image-it outweighs the image, never simply disappears. This is even more so the case here, where the sound has the aura of the past, the mystery of the invisible and the quality of a failed revolution, and where, comparatively, the images relate to commonplace, apparently impoverished, contemporary life. As one experiences the work, the sound-image inconsistency is thus not always palpable, varying in intensity from one moment to the next, oscillating between simultaneity and non-simultaneity. When the doubleness of the two sources is identified, it becomes extremely difficult_-in fact impossible-to fully grasp together the sound and the image, the past and the present. But the persistence

29. Hal Foster, "An Archival Impulse," October, n ${ }^{\circ}$ 110, Fall 2004, p. 4.

30. Christian Marclay, "Conversation entre Michael Snow et Christian Marclay," in Replay Marclay, Exposition Musée de la musique 9 mars-24 juin 2007, Paris, Musée de la musique, Réunion des musées nationaux, 2007, p. 131 (our translation). 
of our perceptual training also means that our first reflex is to overcome this cleavage. Most of the time, one is torn-for the sake of intelligibility-between abandoning the image for the sake of the sound or the sound for the survival of the image. It is only when the video proposes motionless representations, namely images of monuments (statues, the palace, tombs, famous buildings, the stadium), that the visual and the aural can more intelligibly coexist for the spectator.

Let us insist, however, on this point: despite our perceptual efforts, this coexistence never leads to a present-past reconciliation. Rather, the images of Santiago today appear (on the surface at least) oblivious to the past. When the camera catches persisting symbols of communism, for example, they emerge as obsolete relics in contrast to the communist and socialist discourses of 1973; and when the soundtrack transmits ideological debates of 1973, the video camera catches a 2007 view of an empty television studio whose multicolour flashing light projections propel us in the world of the spectacle. In short, the perceptual experience of image-sound simultaneity is a split one, while our highly trained filmic habits and multitask desires keep fighting to deny the split. As such, September 11, 1973_Santiago, Chile's simultaneity is a temporal and perceptual procedure which may well refer to History but refutes the passage that constitutes it since modernity, what Dolev names "the becoming present of future events and then their becoming past."

Most notably in September 11, 1973_Santiago, Chile then, today's regime of time management as best manifested in multitasking (today's normalized perceptual simultaneity par excellence) becomes what high technology consultant Linda Stone has called "continuous partial attention," or the unsustainability of full continuous attention to different media stimuli. In this, the installation explores the findings on multitasking of contemporary psychology and neuroscience. Indeed, as cognitive psychologists Michael Eysenck and Mark Keane have recently concluded:

(a)lthough some studies seem to suggest that two complex tasks can be performed together without disruption, closer readings of the studies do not necessarily prove that. There are often signs of interference. [...] Two tasks are performed well together when they are dissimilar, when they are relatively easy, and when they are well practiced. In contrast, the worst levels of performance occur when two tasks are highly similar, rather difficult, and have been practiced very little. ${ }^{31}$

31. Michael W. Eysenk and Mark T. Keane, "Attention and Performance Limitations," in Daniel J. Levitin (ed.), Foundations of Cognitive Psychology: Core Readings, Cambridge, MIT Press, 2002, p. 380 and p. 395. 
One key study, directed by psychologist Hal Pashler, is particularly relevant to the question of the suspension of time in its assessment of the durational temporality of multitasking. Testing the brain's ability to respond to two different sounds in quick succession, Pashler "found that the brain stalls fractionally before responding to the second stimulus"; while the second sound is perceived, the brain requires time, if only milliseconds, to systematize a response. Unlike the computer, the human brain isn't structured as a parallel but a serial processor. Multitasking is defined here as task switching and the brain becomes "more of a time-share operation" than a means of "concurrent processing." 32 This is exactly how Ohanian's installation interpellates the spectator, how his installations (and I borrow here from Foster's discussion of the archival impulse) "call out for human interpretation." 33 The suspension of time produced by multitasking as an optimum of time management disintegrates as it introduces gaps, distances, hiccups between coexisting events or coexisting times.

In his study of the historical narrative, Paul Ricœur enounces a postulate which relates directly to this state of affairs. "Time becomes human time, he writes, inasmuch as it is narratively articulated." 34 It is through the narrative that history keeps a link with our basic competence to follow a story, as well as with the cognitive operations of narrative comprehension by which history "obliquely" continues to relate to the field of human action and its basic temporality. 35 The absence, in September 11, 1973_Santiago, Chile, of any resolved form of representation of the past, present or future, of history tout court, means that it is up to the spectator, through his or her multitasking and film response training, to take up a narrative with the fragments of the coexisting documents, a narrative by which one can think "the mortal time of phenomenology and the public time of narrative sciences" together..$^{36}$ In this, the spectator adopts the function of the witness, a function that takes a crucial role in Ricœur's important supplement to his study on the historical narrative-Memory, History, Forgetting (2000;

32. Hal Pashler, "Dual-Task Interference and Cognitive Architecture," colloquium paper, University of California, San Diego, September 23, 2004; and http://dual.task.org/ images/o8MULTITASK.html.

33. Hal Foster, "An Archival Impulse", p. 5.

34. Paul Ricœur, Temps et récit 1. L'intrigue et le récit historique, Paris, Éditions du Seuil, coll. "Points. Essais", 1983, p. 17 (our translation).

35. Paul Ricœur, Temps et récit 1. L’intrigue et le récit historique, p. 167 (our translation).

36. Paul Ricœur, Temps et récit 1. L’intrigue et le récit historique, p. 161 (our translation). 
2004) - written "because he had, as it were, forgotten forgetting." 37 According to Ricœur, the witness's testimony is the foundation of history, one that sustains the whole process of making history. For, within the historical sphere, testimony doesn't end with the constitution of archives but resurfaces at the level of the representation of the past through the written or visual narrative. ${ }^{8}$ In September 11, 1973_Santiago, Chile, testimony lies, fractionalized, in Guzmán's document, in the testimonies of the witnesses he interviews (of which we only hear the voices), in Ohanian's own visual document of present Santiago, in his creation of an installation. The sound and image splitting of the documents is operated to privilege another witness who can engage narratively with the work: the spectator. It is there that a post-tenseless representation of historical time, a post-tenseless aesthetics of the passage of time, can come about, if it is to come about.

These mental processes interconnect practices of dissonances, gaps, heterochronies, representation, and interpretation, all of which have to do with return, a not-so-smooth return. Not only the return of the past-with the understanding that the past never fully returns - but, more fundamentally, the display of the path by which oblivion relates to remembrance, memory and collective history: devoid of any physical or mnemonic traces of its reality, the past ceases to exist; but it is this fragility of the archive (the fact that it can disappear or simply be ignored) that motivates the necessity to recall these traces. "Forgetting, writes Ricœur, is the emblem of the vulnerability of the historical condition in its entirety." 39 It is so, as Hayden White's account of Ricœur's Memory, History, Forgetting points out, because history (as a modern practice) has usually been written "to cover over or hide or deflect attention from 'what really happened' in the past by creating an 'official version' that substitutes a part of the past for the whole," and because of the numerous political programs of modernity "designed, as it seems, to abject that very humanity that the rest of 'history' seemed to have been striving to create." ${ }^{\prime \prime}$ The spectator's perceptual confrontation of two cut documents that fail to cohere but launch their openness one vis-à-vis the other initiates a narrativity which is precisely this act by which a spectator is required to insert forgetting or oblivion (the "_" of the title) in his or her récit historique. The histo-

37. Hayden White, "Guilty of History? The Longue Durée of Paul Ricoeur," History and Theory, vol. $46, \mathrm{n}^{\circ}$ 2, May 2007, p. 233.

38. Paul Ricœur, La mémoire, l'histoire, l’oubli, Paris, Éditions du Seuil, coll. "Points. Essais", 2000, p. 181-182.

39. Paul Ricœur, La mémoire, l'histoire, l'oubli, p. 374.

40. Hayden White, "Guilty of History? The Longue Durée of Paul Ricoeur," p. 237238. 
rical narrative is not an answer to oblivion-the possibility to represent the whole of history once all oblivions have been recovered, the possibility to unify past and present-but the acknowledgement of oblivion in the historical condition. It is this very integration that offers the possibility of a renewed connection between past and present, an inventive redeployment of the passage of time within the equally real, equally valid spaces of Hidden, between the frames of Seven Minutes Before and between the two documents of September 11, 1973_Santiago, Chile, a conception that entails the abandonment of pivotal concepts of modern history, including time theology, original trauma, anticipated salvation, utopia, and damnation. As the spectator engages in the post-tenseless deployment of "the becoming present of future events and then their becoming past," he or she is actually engaged in a replay of a mediated past where past and present are brought together with the gaps of oblivion. The installation's elaboration of a space of oblivion provides a crucial interval for the re-interpretation of history from the part of the spectator. The possibility of re-interpretation is what conveys a sense of futurity to the historical discourse. The outcome of this futurechange or status quo? - remains of course unknown but the re-interpretation of the Chilean archives it presupposes does bring in a key element in our reception of the work: the notion of democracy. The suspension of the passage of time is after all an aesthetic materialization of the 1973 coup's suspension of democracy, which did in many ways suspend the passage of democratic time.

In the aftermath of the military coup of 1973, many European countries, namely France, Germany, Italy and Sweden where politicians followed closely Allende's attempt to create socialist reforms democratically, were struck by the following: the Chilean military, with initial support from the US government, brought down the democratically elected socialist Unidad Popular government and initiated a seventeen-year dictatorship led by General Augusto Pinochet using repression against the regime dissidents (a repression assumed to be responsible for the death of over 3000 people and the imprisonment of over 100 ooo people). The simultaneous replay of two cut documents related to the past and the present of Santiago, the tenseless rendering of these two temporalities, reopens this reflection on democracy in light of the present, while forcing us to reassess the utopia attached to the final quote of Guzmán's document: "History is ours, it is the work of the people." What remains of Allende's Unidad Popular's democratic attempts? Was democracy in Chile ever achieved? And, beyond Chile, what constitutes a democracy? In his study on Chilean democracy, historian José Del Pozo has maintained that the very possibility of the military coup in 1973 made manifest how, despite democratic elections, the military received the support of many 
groups of Chilean society (entrepreneurs, the political right, judges, high functionaries, and sections of the Christian Democratic Party) who did not hesitate to re-enact repressive forces of the past after realizing that they had lost control over the country. ${ }^{41}$ It is also clear that the economic crisis which emerged under the Allende government in 1972-a crisis which led to major strikes in the work force-together with Allende's governance by decree threatened the democratic institutions from within. Even today, research by sociologist Manuel A. Garretón concludes that, despite the democratic election of the socialist Concertación candidate Michelle Bachelet in 2005, democracy is "incomplete and qualitatively poor": although there has been significant progress in matters of human rights and political constitution reform, the Concertación still needs to transform the authoritarian institutions inherited from Pinochet-a reform that stagnates because of the government's decision to privilege political stability and economic growth. ${ }^{42}$

Such has been the productivity of the combined suspension of time and perception: the spectator's engagement in the thinking and re-interpretation of the historical condition, a reactivation of the passage of time but outside teleology and within the remembering of forgetting in the récit historique, a questioning of the persistence or the waning, value or disvalue of democracy and utopia. September 11, 1973_Santiago, Chile, I have been arguing, is a key contributor to the aesthetic exploration of the conditions of possibility of historical time: although it moves away-without any concession-from the explanation and representation of history, although it refuses to fully recover the past event or to indicate where its history is leading us, it insists on the requirement not to abandon the event, as well as the need to confront the never fully recovered past and present. It does so by creating for the spectator the perceptual conditions of possibility of historical narrativity, which takes the form here of mental processes that remain impalpable to others. The récit historique is the responsibility of each observer and, as such, is never made public or manifest by the artwork. Moreover, it is elaborated by spectators as their perceptual experience of suspended time is split between the simultaneity of an aural past and a visual present-an experience that keeps intensifying the now of a disjointed perception. The installation, in short, is more

41. José Del Pozo, Le Chili contemporain: quelle démocratie?, Montréal, Nota Bene, coll. "Essais critiques", 2000.

42. Manuel Antonio Garretón, Incomplete Democracy: Political Democratization in Chile and Latin America, trans. R. Kelly Washbourne with Gregory Horvath, Chapel Hill, University of North Carolina Press, 2006. 
about the conditions of possibility of futurity than its noticeable actualization. By setting into play perceptual discrepancies for the spectator, it is an enabler rather than a direct producer of historical time, one that is inseparable from the simultaneous unfolding of different categories of time. 